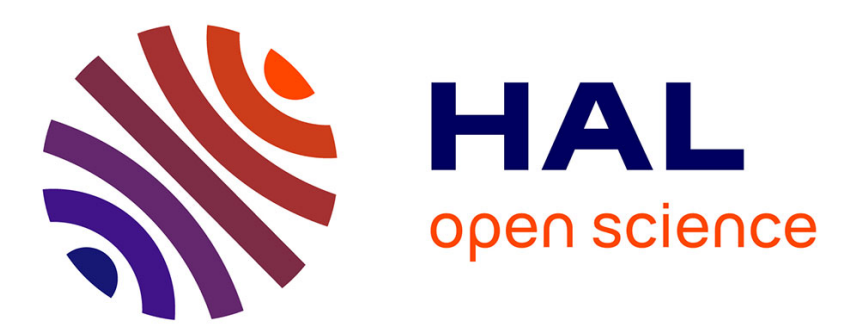

\title{
Collective Intelligence for Decision-Making in Complex Environments: Literature Review
}

Daniela Rincón, Jhonatan Valdes, Luz Bohórquez

\section{To cite this version:}

Daniela Rincón, Jhonatan Valdes, Luz Bohórquez. Collective Intelligence for Decision-Making in Complex Environments: Literature Review. 14th IFIP International Conference on Artificial Intelligence Applications and Innovations (AIAI), May 2018, Rhodes, Greece. pp.471-480, 10.1007/978-3-31992007-8_40. hal-01821039

\section{HAL Id: hal-01821039 \\ https://hal.inria.fr/hal-01821039}

Submitted on 22 Jun 2018

HAL is a multi-disciplinary open access archive for the deposit and dissemination of scientific research documents, whether they are published or not. The documents may come from teaching and research institutions in France or abroad, or from public or private research centers.
L'archive ouverte pluridisciplinaire HAL, est destinée au dépôt et à la diffusion de documents scientifiques de niveau recherche, publiés ou non, émanant des établissements d'enseignement et de recherche français ou étrangers, des laboratoires publics ou privés. 


\title{
COLLECTIVE INTELLIGENCE FOR DECISION- MAKING IN COMPLEX ENVIRONMENTS: Literature Review
}

\author{
Daniela Rincón. ${ }^{1}(0000-0001-7546-0720)$, Jhonatan Valdes. ${ }^{2}$ (0000-0002-7131-9540), \\ and Luz Bohórquez. ${ }^{3}(0000-0001-8401-3471)$ \\ ${ }^{1}$ Universidad Distrital Francisco José de Caldas, Bogotá D.C., Colombia \\ drincolecorreo.uditrital.edu.co \\ jdvaldesglcorreo.udistrital.edu.co \\ lebohorqueza@udistrital.edu.co
}

\begin{abstract}
The growing complexity of the environment makes explicit the fact that Human Social Systems must develop mechanisms that allow them to increase agility in decision-making. An alternative to achieve this is found in Collective Intelligence, which has been widely studied in Natural Social Systems, in Artificial Social Systems, and in Human Social Systems. Despite the research carried out in this last field, there is no clarity regarding the aspects that facilitate its understanding and emergency. This document identifies the structural and dynamic features in different Collective Intelligence models selected in the context of Human Social Systems. Finally, the possibility of proposing other features to be considered is discussed from the review of the factors that have explained the emergence of Collective Intelligence in Natural and Artificial Social Systems, and they are assessed in order to design Collective Intelligence models in future research.
\end{abstract}

Keywords: Collective Intelligence, Swarm Intelligence, Complex Systems, Human Social Systems.

\section{Introduction}

Human Social Systems must develop ways that make possible to increase the agility to adapt to changing conditions in the environment, considering its increasing complexity. Adaptation is understood from the biological - evolutionary perspective, and involves variations that enable the system to provide solutions to survive in the environment [1].

Collective intelligence (CI), studied in Natural Social Systems (NSSs), in Artificial Social Systems (ASSs) and in Human Social Systems (HSSs), is an option to increase agility in adapting to changing environmental conditions. Research in NSSs has its origin in Swarm Intelligence (SI); term that was introduced for the first time by Beni and Wang [2], when they investigated the emergence of collective behaviors. This concept was later extended by Bonabeau, Dorigo and Theraluz [3] including any effort to design algorithms for problem solving inspired by the collective behavior of social insects. 
In human social systems, CI was formalized since the 1990s, by authors such as Lévy [4], Pór [5] and Malone [6]; and it is understood from the behaviors and decisions that arise from the crowds. CI appears as a mean to take advantage of the large volumes of information, which arise permanently on account of technological development, in the generation of new knowledge that acts as a society engine. [4]

The different proposals of CI in HSSs have been oriented to the design of systems with capacities to solve problems in flexible, robust, adaptive, agile and resilient ways, allowing them to survive in highly changing environments [7]. However, a consensus regarding what are the structural and dynamic aspects that facilitate their understanding and emergence does not exist thus far.

\section{$2 \quad$ Methodology}

The literature available in CI, mainly in NSSs and ASSs, is extensive and has a broad trajectory. The study was carried out in three stages: S1 embraces wide database searches. Based on the results of S1, an emphasis in certain authors who are identified as relevant (Table 1) is given on $\mathrm{S} 2$, and finally, $\mathrm{S} 3$ focuses on the analysis of the obtained information.

Table 1. Main Databases, Journals and Authors consulted.

\begin{tabular}{|c|l|l|l|}
\hline $\begin{array}{c}\text { Collective Intelligence } \\
\text { review }\end{array}$ & \multicolumn{1}{|c|}{ Databases } & \multicolumn{1}{|c|}{ Main Journals } & \multicolumn{1}{c|}{ Main Authors } \\
\hline & ScienceDirect & MIT Sloan Management Review & Bonabeau, E (1999) \\
& SpringerLink & Administrative Science Quarterly & Secundo G. (2012) \\
& Malone, T.W. (2010) \\
Natural and Artificial & Scopus & Philosophical Logic and Artificial & Lévy, P. (1997) \\
Social Systems & JSTOR & Intelligence & Atlee, T. (2000) \\
& World Scientific & Artificial Intelligence & Gerardo Beni (1993) \\
& Elsevier & Advances in Complex Systems & Jing Wang (1993) \\
& IEEE & Integrative and Comparative Biology & Malone, T.W. (2008) \\
& ScienceDirect & MIT Sloan Management Review & Pévy, P. (2004) \\
& SpringerLink & Cognitive Systems Research & McHugh K.A. (2016) \\
\hline \multirow{4}{*}{ Human Social Systems } & Scopus & Strategic management journal & \\
& APA PSYCNET & Advances in Complex Systems &
\end{tabular}

The methodology proposed for the development of the present investigation was carried out in 4 stages indicated. (Table 2.)

Table 2. Stages of the methodology. Prepared by authors.

\begin{tabular}{|l|l|}
\hline Stage & \multicolumn{1}{c|}{ Definition } \\
\hline S1 & CI literature review in NSSs and ASSs. CI literature review in HSSs \\
\hline S2 & $\begin{array}{l}\text { Identification of the structural and dynamic features that different models applying CI in HSSs have in } \\
\text { common. (Structural factors refer to features that the system structure should have. Dynamic factors focus on } \\
\text { the features that emerge from the structure of the system }\end{array}$ \\
\hline S3 & $\begin{array}{l}\text { Comparison of the NSSs and ASSs structural and dynamic factors with those of HSSs identified in S2, in order } \\
\text { to recognize differences and similarities. }\end{array}$ \\
\hline
\end{tabular}


\begin{tabular}{|l|l} 
S4 & Structuring of new approaches and features that facilitate the emergence of CI in HSSs
\end{tabular}

\section{Collective Intelligence in Natural and Artificial Social Systems}

Research on collective behavior in NSS has its main background in Swarm Intelligence (SI). The expression Swarm Intelligence was introduced by Beni \& Wang [2] when they studied decentralization and capacity for self-organization in the robotic systems context. The emergence of intelligent solutions presented by the colonies of ants, bees, termites, wasps, has surprised several researchers due to the high levels of robustness and flexibility [3].

\section{Collective Intelligence in Human Systems}

High levels of robustness, flexibility, adaptability, cooperation, Self-Organization and Collective Intelligence for environmental solution problems that NSSs and ASSs exhibit, has aroused the interest of various authors to design HSSs models. [16]. The research conducted by McHugh [17] evidences that organizations with higher levels of CI present higher quality of decisions in terms of precision, agility [18] variety of knowledge [19], breadth and depth [20]. As mentioned by Alberts [21], even when an absence of agility does not represent a threat to existence, it is very expensive.

To date there are important investigations for CI in HSSs from different disciplines such as psychology [22], politics [18] and economics [23]. Table 3 presents some of the CI proposals in HSSs. The registered proposals cover different sectors (health, education, energy, among others) and are mainly oriented towards decision making.

Table 3. Models with CI Applications. Prepared by the Authors.

\begin{tabular}{|l|l|}
\hline ID & \multicolumn{1}{|c|}{ PROPOSAL } \\
\hline 1 & $\begin{array}{l}\text { Collective Intelligence and Online Learning Communities [24]. Gea, M., Soldado, R. M., \& Lenguajes, D. (2011). } \\
\text { New forms of non-formal learning skills in digital communities through Collective Intelligence. }\end{array}$ \\
\hline 2 & $\begin{array}{l}\text { Collective intelligence for promoting changes in behavior: a case study on energy conservation [25].Piccolo, L. } \\
\text { S. G., Liddo, A. De, Burel, G., Fernandez, M., \& Alani, H. (2017) .Build knowledge in a collaborative manner } \\
\text { around the conservation of energy. }\end{array}$ \\
\hline 3 & $\begin{array}{l}\text { Collective Intelligence Meets Medical Decision-Making: The Collective Outperforms the Best Radiologist } \\
\text { [26].Wolf, M., Krause, J., Carney, P. A., Bogart, A., \& Kurvers, R. H. J. M. (2015).The proposal studies the } \\
\text { way as certain established rules are used by a team of specialists in mammograms diagnosis and treatments. }\end{array}$ \\
\hline 4 & $\begin{array}{l}\text { Fostering collective intelligence education [27]Meza, J., Monguet, J. M., Grimón, F., \& Trejo, A. } \\
\text { (2016).Teaching IC model using a virtual platform to promote shared learning between students and teachers }\end{array}$ \\
\hline 5 & $\begin{array}{l}\text { How common standards can diminish collective intelligence: a computational study. [28]Morreau, M., \& Lyon, } \\
\text { A. (2016) Create knowledge shared by a group of specialists through the collection of information and individual } \\
\text { experiences to improve the medical diagnoses efficiency }\end{array}$ \\
\hline
\end{tabular}




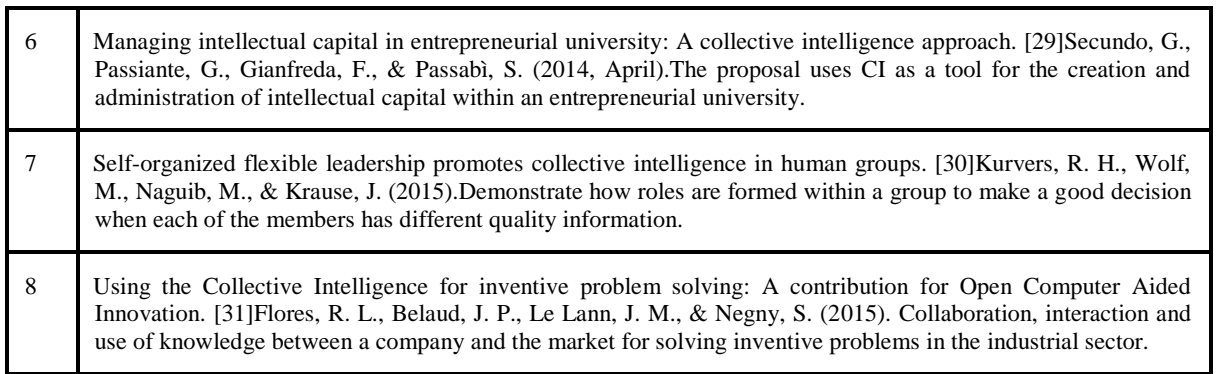

Proposals registered in Table 3 provide the framework that enables the identification of structural and dynamic factors that explain the CI in the studied systems. In Table 3, each model is identified by an ID number that will be used to reference the model in some sections of the document.

\section{Gap between Natural and Artificial Systems Compared to Human Systems}

The aim of this section is to identify the structural and dynamic features that facilitate the understanding of CI in NSSs and ASSs to enrich CI proposals in HSSs. In this research it is recognized that NSSs and ASSs do not have a specific and predetermined purpose as it happens in HSSs e.g. profitability. The pre-specification of the system's purpose can reduce the complexity this can absorb. In order to know how the HSSs could enhance their CI characteristics and improve decision-making in environments with high levels of uncertainty, it is necessary to contrast features they have in common with the NSSs and the ASSs. The structural and dynamic features identified in NSSs and ASSs, HSSs and the gap between Natural and Artificial Systems Compared to Human Systems are shown below (Table 4).

Table 4. Structural and dynamic features in NSSs and ASSs

\begin{tabular}{|c|c|c|}
\hline NSSs and ASSs & HSSs & \multirow{2}{*}{ Gap } \\
\hline \multicolumn{2}{|c|}{ Structural Features } & \\
\hline $\begin{array}{l}\text { Central Controller absence. The } \\
\text { centrality is a structural attribute of } \\
\text { the network nodes and not of the } \\
\text { actors themselves, i.e. it is } \\
\text { understood from the position } \\
\text { occupied by an agent in the system } \\
\text { [8]. Control is oriented to guarantee } \\
\text { the fulfillment of the objectives or } \\
\text { the development of tasks [9]. } \\
\text { Diverse investigations have shown } \\
\text { that the CI exhibited by social } \\
\text { insects is characterized by the }\end{array}$ & $\begin{array}{l}\text { Autonomy. It is described as } \\
\text { multidisciplinary groups with self- } \\
\text { organizing that operate with a decentralized } \\
\text { authority [33]. For a collective to be } \\
\text { intelligent, the autonomous perceptions of } \\
\text { those who make up the group must be } \\
\text { mobilized and respected: call for the active } \\
\text { expression of singularities, creativities and } \\
\text { competences. } \\
\text { In models } 1,2,3 \text { and } 4 \text { there is not a central } \\
\text { node that makes decisions and exercises } \\
\text { control over others, but, a decision is made } \\
\text { according to a series of pre-established rules. }\end{array}$ & $\begin{array}{l}\text { Decentralization } \\
\text { Autonomy. While within NSSs } \\
\text { and ASSs exist a full SO in the } \\
\text { absence of a central controller to } \\
\text { provide an agile solution to the } \\
\text { group and environment needs, in } \\
\text { HSSs there is not a complete } \\
\text { decentralization. In NSSs, the } \\
\text { division of labor is usually } \\
\text { determined by morphological } \\
\text { features. } \\
\text { From the analyzed models that } \\
\text { use digital tools to fulfill their } \\
\text { purpose (1, 2, 4, 6, and } 8 \text { ), } \\
\text { platforms are means for }\end{array}$ \\
\hline
\end{tabular}




\begin{tabular}{|c|c|c|}
\hline $\begin{array}{l}\text { absence of a central controller and a } \\
\text { hierarchical structure. [10]. }\end{array}$ & & \multirow{6}{*}{$\begin{array}{l}\text { cooperation between individuals } \\
\text { with different roles and achieve a } \\
\text { common goal, therefore, a central } \\
\text { controller does not exist. } \\
\text { Direct/Indirect } \\
\text { Communication, Information } \\
\text { Processing, Shared Knowledge } \\
\text { and Collaboration. } \\
\text { Communication in NSSs, ASSs } \\
\text { and HSS seeks to process } \\
\text { information in an effective and } \\
\text { agile way among the system } \\
\text { agents. Nevertheless, agility in } \\
\text { HSS interactions cannot be } \\
\text { considered as effective as in the } \\
\text { NSSs. Authors such as Dale, } \\
\text { Fusaroli, Duran and Richardson } \\
\text { [32] propose the study of } \\
\text { synchrony patterns between } \\
\text { individuals. On the other hand, } \\
\text { Barlow and Dennis [37] raise the } \\
\text { importance of the medium in } \\
\text { which the homogeneity in the } \\
\text { signals interpretations is carried } \\
\text { out to achieve coherent responses. }\end{array}$} \\
\hline $\begin{array}{l}\text { Direct Interaction. Some forms of } \\
\text { direct communication in social } \\
\text { insects are antennae, trophalaxis } \\
\text { (feeding one another), mandibular } \\
\text { contact, eye contact, chemical } \\
\text { contact, among others [3]. Another } \\
\text { example is birds attracted to sites } \\
\text { where other birds already nest. This } \\
\text { imitative behavior is a positive } \\
\text { feedback process in which an } \\
\text { individual follows the "I nest near } \\
\text { where you nest" rule. [11]. }\end{array}$ & $\begin{array}{l}\text { Direct communication. Gestures, language, } \\
\text { context and prosody (pronunciation and } \\
\text { accentuation) influence the interaction } \\
\text { between agents. [32]. Direct communication } \\
\text { characterizes model } 6 \text { as soon as group } \\
\text { decisions between agents were made face to } \\
\text { face in the university facilities. }\end{array}$ & \\
\hline $\begin{array}{l}\text { Indirect interaction. Refers to } \\
\text { communication processes that arise } \\
\text { through the modification of the } \\
\text { environment. When termites build } \\
\text { their nests, they send stimuli to } \\
\text { others through pheromones and it } \\
\text { causes other termites to build their } \\
\text { nests close to the one previously } \\
\text { placed [12]. Indirect interaction also } \\
\text { called stigmergy by the French } \\
\text { biologist Grassé [12] allows to } \\
\text { understand the cooperative behavior } \\
\text { that arises among insects. }\end{array}$ & $\begin{array}{l}\text { Indirect communication. Agents do not } \\
\text { require to perceive the existence of others. } \\
\text { However, the activities that are carried out in } \\
\text { the system have consequences for all its } \\
\text { actors [22]. In model } 1,2,4,8 \text { the } \\
\text { information exchange is generated through } \\
\text { non-explicit assumptions in virtual media, } \\
\text { without a face-to-face contact. }\end{array}$ & \\
\hline $\begin{array}{l}\text { Division of roles. It allows creating } \\
\text { specialized groups that perform } \\
\text { tasks better than if they were } \\
\text { performed by a single agent [13], } \\
\text { this ensure that if a member fails in } \\
\text { the development of the labor, colony } \\
\text { is still functioning through the work } \\
\text { of other agents. }\end{array}$ & $\begin{array}{l}\text { Distributed Information Processing. } \\
\text { Information is not concentrated on specific } \\
\text { groups but rather integrates naturally to the } \\
\text { entire human activities and returns to the } \\
\text { hands of all. Collectives communicate } \\
\text { transversally without a hierarchical structure. } \\
{[34] \text { In model } 4 \text { ideas are produced }} \\
\text { individually-collectively and are } \\
\text { hierarchized; then, they are assessed. }\end{array}$ & \\
\hline \multicolumn{2}{|c|}{ Dynamic Features } & \\
\hline $\begin{array}{l}\text { Self-organization (SO). It Is } \\
\text { understood as the emergence of } \\
\text { collective behaviors from } \\
\text { interactions between agents [14] or } \\
\text { as a set of dynamic mechanisms in } \\
\text { which global-level structures appear } \\
\text { from an interactions system among }\end{array}$ & $\begin{array}{l}\text { Self-Organization. Behavior patterns } \\
\text { emerges from interaction. These patterns are } \\
\text { formed and reformed spontaneously and } \\
\text { continuously at multiple levels within the } \\
\text { system. The objective is to understand how } \\
\text { they are determined by the interactions of the } \\
\text { agents to carry out the appropriate } \\
\text { interventions in the system. [35]. In models } \\
1,2 \text { and } 4 \text { when an individual participates }\end{array}$ & \\
\hline
\end{tabular}




\begin{tabular}{|c|c|c|}
\hline $\begin{array}{l}\text { the components of different levels } \\
\text { [15]. }\end{array}$ & $\begin{array}{l}\text { and contributes new ideas, the other agents } \\
\text { are stimulated and actively participate. }\end{array}$ & \multirow{3}{*}{$\begin{array}{l}\text { time some system conditions can } \\
\text { be changed. } \\
\text { Adaptability and Flexibility. } \\
\text { Different species and biological } \\
\text { systems look for adapt agilely to } \\
\text { changing and emerging } \\
\text { environments. Some approaches } \\
\text { have been made in the proposals } \\
\text { that use virtual media as } \\
\text { mechanisms to achieve the } \\
\text { proposed intentions. In models } \\
\text { that perform medical diagnoses } \\
\text { using CI (3, 5) low level of } \\
\text { adaptability is evidenced. }\end{array}$} \\
\hline & & \\
\hline $\begin{array}{l}\text { Adaptability. SO allows to explain } \\
\text { adaptability as the capacity of } \\
\text { modify and being modified as well } \\
\text { as adjust itself to the changing } \\
\text { environment. }\end{array}$ & $\begin{array}{l}\text { Adaptability. If a link is congested, the } \\
\text { interconnection between agents must allow } \\
\text { an alternative path to be used to reach its } \\
\text { destination, whether it is information or a } \\
\text { decision. [36]. In the model } 4 \text {, the students } \\
\text { feedback towards the proposed ideas } \\
\text { changes according to the other students } \\
\text { opinions. }\end{array}$ & \\
\hline $\begin{array}{l}\text { Flexibility. Denotes the capacity of } \\
\text { changing within the system. }\end{array}$ & $\begin{array}{l}\text { Collaboration. The capacity of a multi- } \\
\text { agent system is not determined by a simple } \\
\text { agent but by the intelligence shown by } \\
\text { mutual coordination from the interactions } \\
\text { that are generated in the system. [23] } \\
\text { Information and Communication } \\
\text { Technologies (ICTs) are used in model } 8 \text { as } \\
\text { facilitators in the collaborative environments } \\
\text { creation to gather resources and experts to } \\
\text { relate existing knowledge. }\end{array}$ & $\begin{array}{l}\text { Agility. In model } 2 \text { and } 8 \\
\text { technology is used to create an } \\
\text { agile model with the aim of } \\
\text { generating shared awareness } \\
\text { around the environmental care } \\
\text { and open innovation through the } \\
\text { improvement of communication. } \\
\text { Apparently, these models allow } \\
\text { solutions to different cases in less } \\
\text { time and with better results. }\end{array}$ \\
\hline $\begin{array}{l}\text { Robustness. Refers to the ability to } \\
\text { continue operating despite failures } \\
\text { that occur at individual level [3] }\end{array}$ & $\begin{array}{l}\text { Shared knowledge. One person can } \\
\text { represent a source of knowledge enrichment } \\
\text { for another one. By associating their } \\
\text { competences, they demonstrate that they can } \\
\text { do a better job together than apart. [22, 34]. } \\
\text { The model } 7 \text { have two roles. Leaders have } \\
\text { the most accurate information and decide } \\
\text { quickly. }\end{array}$ & \\
\hline
\end{tabular}

\section{Discussions and Future Research Lines}

The development of this article has allowed to understand and identify structural and dynamic features present in the NSSs, ASSs and HSSs. Within the features found in the HSSs models closest to the characterization in NSSs and in ASSs, are the absence of a central controller (NSSs) and autonomy (HSSs). Despite the similarity, the roles within the system are predefined. It is necessary that the function an actor plays within the system properly emerges from the interactions with the environment. On the other hand, proposals where virtual platforms are included, information processing presents a good approach to what is set in the NSSs; virtual media allows greater flexibility in the systems. However, quality of input information determines how agile the system can be and its capacity for self-organization; therefore, collaboration emerges as a possible response to avoid aspects such as opportunism and other characteristics of the human being that provide limited information and slow down the system. 
A proposal for future research in the CI models design is to identify the range in which the number of participating actors should be found to decrease the influence of specific nodes, and ensure that it does not decrease the level of interactions between agents and the environment. The use of ICTs tools could improve the design of a CI model, creating information bases, supporting them on adaptive learning and leading the system to adapt itself to changes in the environment.

\section{References}

1. Bock WJ (1980) The Definition and Recognition of Biological Adaptation. Am Zool 20:217-227 . doi: 10.1093/icb/20.1.217

2. Beni G, Wang J (1993) Swarm Intelligence in Cellular Robotic Systems. Robot Biol Syst Towar a New Bionics? 703-712 . doi: 10.1007/978-3-642-58069-7_38

3. Boneabeau E, Dorigo M, Theaulaz G (1999) Swarm Intelligence: From Natural to Artificial Systems

4. Lévy P (1997) L'intelligence collective. Pour une anthropologie du cyberespace. 246

5. Pór G (1995) The quest for collective intelligence. In Community Building: Renewing Spirit and Learning in Business. California

6. Malone TW (2008) What is collective intelligence and what will we do about it? Collect. Intell. Creat. a Prosperous World Peace

7. Alberts D, Hayes R (2003) Power to the edge: Command... control... in the information age. (CCRP).

8. Hossain L, Wu A (2009) Communications network centrality correlates to organisational coordination. Int J Proj Manag 27(8):795-811

9. Simons R (1994) Levers of control: How managers use innovative control systems to drive strategic renewal.

10. Greene MJ, Gordon DM (2007) Interaction rate informs harvester ant task decisions. Behav Ecol 18:451-455 . doi: 10.1093/beheco/arl105

11. Camazine S (2003) Self-organization in biological systems. Princeton University Press.

12. Grassé (1959) The automatic regulations of collective behavior of social insect and " stigmergy." J Psychol Norm Pathol (Paris) 57:1-10

13. Park JC et al (2007) Measures to take advantage of the collective collective intelligence of the Web 2.0 platform. Rev Korean Soc Internet Inf 8 No. 2:15-20

14. Kauffman JM, Hallahan DP (1995) The illusion of full inclusion: A comprehensive critique of a current special education bandwagon.

15. Bonabeau E, Theraulaz G, Deneubourg JL, Aron S, Camazine S (1997) Selforganization in social insects. Trends Ecol Evol 12(5):188-193

16. Atlee T, Por G Collective Intelligence as a Field of Multi - disciplinary Study and Practice. Community Intell

17. McHugh KA, Yammarino FJ, Dionne SD, Serban A, Sayama H, Chatterjee S (2016) Collective decision making, leadership, and collective intelligence: Tests with agentbased simulations and a Field study. Leadersh Q 27:218-241 . doi: 10.1016/j.leaqua.2016.01.001

18. Gilliland SW, Landis RS (1992) Quality and quantity goals in a complex decision task: Strategies and outcomes. J Appl Psychol 77(5):672-681 . doi: 10.1037/00219010.77.5.672

19. Bantel KA, Jackson SE (1989) Top management and innovations in banking: Does the composition of the top team make a difference?. Strateg Manag J 10(S1):107-124 . doi: 10.1002/smj.4250100709 
20. Kraiger K, Wenzel LH (1997) A framework for understanding and measuring shared mental models of team performance and team effectiveness. E Salas, MT Brannick, C Prince (Eds),

21. Alberts DS (2011) The agility advantage: A Survival Guide for Complex Enterprises and Endeavors

22. Marsh L, Onof C (2008) Stigmergic epistemology, stigmergic cognition. Cogn Syst Res 9:136-149 . doi: 10.1016/j.cogsys.2007.06.009

23. Guo QL, Zhang M (2009) Multiagent-based scheduling optimization for Intelligent Manufacturing System. Int J Adv Manuf Technol 44:595-605 . doi: 10.1007/s00170008-1858-x

24. Gea M, Soldado RM, Gámiz V (2011) Collective Intelligence and Online Learning Communities. In: Information Society (i-Society), 2011 International Conference. pp 336-340

25. Piccolo LSG, De Liddo A, Burel G, Fernandez M, Alani H (2017) Collective intelligence for promoting changes in behaviour: a case study on energy conservation. Ai Soc 0:1-11 . doi: 10.1007/s00146-017-0710-y

26. Wolf M, Krause J, Carney PA, Bogart A, Kurvers RHJM (2015) Collective intelligence meets medical decision-making: The collective outperforms the best radiologist. PLoS One 10:1-11 . doi: 10.1371/journal.pone.0134269

27. Meza J, Monguet JM, Grimón F, Trejo A (2016) Fostering Collective Intelligence Education. 165-172 . doi: 10.1007/978-3-319-28883-3_21

28. Morreau M, Lyon A (2016) How common standards can diminish collective intelligence: a computational study. J Eval Clin Pract 22:483-489 . doi: 10.1111/jep. 12585

29. Secundo G, Passiante G, Gianfreda F, Passabì S (2014) Managing Intellectual Capital in Entrepreneurial University: A Collective Intelligence Approach. 6th Eur Conf Intellect Cap ECIC 2014 209-216

30. Kurvers RHJM, Wolf M, Naguib M, Krause J (2015) Self-organized flexible leadership promotes collective intelligence in human groups. R Soc Open Sci 2:150222 . doi: $10.1098 /$ rsos. 150222

31. Lopez Flores R, Belaud JP, Le Lann JM, Negny S (2015) Using the Collective Intelligence for inventive problem solving: A contribution for Open Computer Aided Innovation. Expert Syst Appl 42:9340-9352 . doi: 10.1016/j.eswa.2015.08.024

32. Dale R, Fusaroli R, Duran ND, Richardson DC (2014) The Self-Organization of human interaction. In: Psychology of Learning and Motivation - Advances in Research and Theory. pp 43-95

33. Ismail S, Malone MS, Van Geest Y (2016) Organizaciones Exponenciales. BUBOK PUBLISHING

34. Levy P (2004) Inteligencia colectiva: por una antropología del ciberespacio. Centro Nacional de Información de Ciencias Médicas (INFOMED)

35. Eoyang GH (2004) Conditions for Self-Organizing in Human Systems. Futuries 28:1059

36. Peters K, Johansson A, Dussutour A, Helbing D (2006) Analytical and numerical investigation of ant behavior under crowded conditions. Adv Complex Syst 9(04):337352 . doi: $10.1142 / \mathrm{S} 0219525906000859$

37. Barlow JB, Dennis AR (2016) Not As Smart As We Think: A Study of Collective Intelligence in Virtual Groups. J Manag Inf Syst 33:684-712 . doi: $10.1080 / 07421222.2016 .1243944$ 